\title{
Addressing transdisciplinary and participation issues to cope with rapid changes shifting marine social ecological systems
}

\author{
Guillotreau Patrice ${ }^{1}$, Trouillet Brice ${ }^{2,{ }^{*}}$, Mahévas Stephanie ${ }^{3}$, Pardo Sophie ${ }^{1}$
}

\author{
1 Université de Nantes, LEMNA, Chemin de la Censive du Tertre, BP 52231, F-44000 Nantes, France \\ 2 Université de Nantes, CNRS, UMR LETG, Chemin de la Censive du Tertre, BP 81227, F-44000 \\ Nantes, France \\ 3 IFREMER, Écologie et Modèles pour l'Halieutique, BP 21105, F-44000 Nantes, France \\ * Corresponding author : Brice Trouillet, email address : Brice.Trouillet@univ-nantes.fr
}

\begin{abstract}
:
This special section is derived from an international transdisciplinary Conference (OCEANEXT) held in 2016. It aimed at contributing to explore new initiatives mixing up scientific expertise and a participatory approach of stakeholders. This conference also ended the COSELMAR project (2013-2017), having brought together almost 170 researchers and resulted in 360 publications and communications. In this special issue, a panel of few communications were converted into peer-reviewed contributions focusing on the need for effective monitoring ahead of potential outbreaks to enhance the adaptive conditions for coastal communities and for more participation of stakeholders in the governance of social ecological marine systems. These few examples witness that transdisciplinary research on marine social ecological systems brings sound outputs, if researchers are willing to go out of their disciplinary comfort zone so as to collaborate with other disciplines and if they are able to change the way research is done within society. As a result, funding big integrating projects such as COSELMAR is essential in a marine realm constantly facing new challenges.
\end{abstract}

Keywords: Marine research, Coastal hazards, Coastal flood, Risks perception, Citizen sciences, Fisheries management 
There is a growing interest in marine sciences to develop 'transdisciplinary research' on the adaptive strategies of coastal communities against global changes affecting marine social ecological systems (Lang et al. 2012). This literature can be found in various research networks and projects, e.g., PICES, Future Ocean, IMBeR (Van Assche et al. 2020, Bograd et al. 2019, Krishnamurty et al. 2018, Guillotreau et al. 2018). The seventeenth Sustainable Development Goals provides an ambitious shared framework to develop innovating knowledge and scenarios of marine social ecological systems at local and global scales (MDG Gap Task Force Report, 2015).

This special issue is derived from an international transdisciplinary Conference (OCEANEXT [1]), and rooted in this strand of literature and goal. It aims at contributing to it by exploring new initiatives mixing up scientific expertise and a participatory approach of stakeholders. Whatever the factors underpinning the detrimental consequences of global change for coastal communities (pathogens, storms, flooding, harmful algal blooms, population size, overexploitation etc.), social responses need to be fast and proportionate in magnitude. Societies must be prepared for surprises and unexpected disturbances, accepting to follow some basic principles to adapt themselves and to increase their level of resilience (Biggs et al. 2015). Among other principles, a polycentric or collaborative governance and the participation of stakeholder is often considered a key factor of success (Folke et al. 2010, Berkes and Ross 2013).

\section{Building transdisciplinary knowledge for social-ecological marine systems: the examples of COSELMAR and OCEANEXT}

COSELMAR (2013-2017) was a research project gathering 5 research units of IFREMER, 1 laboratory of the University of Angers and 11 laboratories of the University of Nantes, in France, along with academic partners and national and international industries. In overall, 169 researchers were involved in the three scientific axes of the project which were: Biodiversity (particularly microalgae) in coastal environment, Adding value to marine resources (e.g., sea water treatment, processing of invasive species), New activities and risks in coastal areas (e.g. wind farms, flooding hazards, global change), to which a specific axis of research integration was added. The aim was to achieve a better understanding of the marine and coastal socio-ecosystems and the associated resources. The project also provided insights into risk management and prevention of natural events and anthropogenic impacts. COSELMAR managed to integrate and promote the transdisciplinary scientific work in order to build a real expertise on potential risks of coastal and marine zones.

Although impossible to fully report in the present issue, the results of this five-year project have been summarized in a final document available on the project website [2]. The website enlights some of the results being presented in details as well. Nearly 360 publications and communications were produced out of the project and more results are still being publicized by the project members. Two summer schools were held in summer 2015, one on Marine Spatial Planning (in relation with the Marine Spatial Planning Research 
Network) and the other one on the ecology of microalgae and molluscs. An transdisciplinary exercise of geo-foresight scenario-building was also developed as part of the integration axis scheme. Researchers were trained for this exercise, met to apply the foresight methodology to the issue of fishing governance, and created three contrasted scenarios of possible future for the fishing industry and the social-ecological system in the Bay of Biscay, increasingly affected by natural and anthropogenic changes. As an example, new uses are challenging the situation of long-standing sectors at sea (i.e., shipping, fishing, shellfish farming), but are also raising new research issues (e.g., multi-use of the sea, assessment of socioeconomic impacts). In particular, the settlement of offshore platforms and equipment (e.g., wind farms) requires specific attention and analysis by researchers about their spatial coverage and location, their design, the bio-colonization by marine organisms, the organization of labour, the legal status of these new floating objects, etc.

Last and not least, the COSELMAR project coordinators (Sophie Pardo and Philipp Hess) organized a large international and multi-disciplinary conference named OCEANEXT on June 8-10 th 2016 , gathering 220 participants coming from 18 different countries [3]. This conference was very unique of its kind by combining plenary sessions involving a broad community of marine researchers on topics as various as integrated multi-trophic aquaculture (Thierry Chopin, University of New Brunswick, Canada), the phytoplankton biodiversity at planetary scale (Chris Bowler, TARA-OCEANS, UK), transdisciplinary insights into integrated ecosystem assessments (Dorothy Dankel, University of Bergen, Norway), the role of foresight studies to integrate science and stakeholders (Luc Van Hoof, IMARES Wageningen, The Netherlands), and parallel sessions on oceans and human health, climate change and marine ecosystems, blue growth, marine renewable energy, marine spatial planning, risk perception and management, harmful algal blooms, etc. Such a diversity of topics and disciplines, having all in common to be sea-related key issues which require to create a transdisciplinary dialogue, made the originality of this research event. The meeting was so successful that a second edition of OCEANEXT took place in Nantes on July $3-5^{\text {th }} 2019$ [4].

In this special issue, some of the communications were converted into peer-reviewed contributions focusing on the need for effective monitoring ahead of potential outbreaks to enhance the adaptive conditions for coastal communities (part 3) and for more participation of stakeholders in the governance of social ecological marine systems (part 4).

\section{New hazards need good monitoring systems and more evaluation of adaptive strategies}

The means deployed by public and private institutions are sometimes not enough to cover a broad open space at sea and follow the slow variables (Folke et al. 2010, Biggs et al. 2015) which may have great consequences for the seafood industry. R. Siano et al. (this issue) suggest to mobilize a large fringe of citizens who can report on marine water discolorations caused by phytoplankton and prevent potential harmful algal blooms (HAB) crises for fishers and fish farmers. A significant number of warnings were given by this citizen approach (called Phenomer), which enabled to register many phenomena, such as red, brown or green tides, out of the area covered by the usual monitoring system. The benefits of the system should be evaluated before generalizing its use.

One way of assessing the system might be inspired by the value chain analysis developed by $V$. Le Bihan and $M$. Catalo (this issue) on the shellfish farming industry. These two authors observed in Southern Brittany (Western part of France) substantial changes coming 
both from environmental modifications and technological innovations which are revealed by their value chain. The frequency of outbreaks pushed some farmers to leave their offshore grounds for nearshore leaseholds and change their cultural practices to cope with this new state of the environment. However, the authors also showed that these adaptive behaviours can be out of reach for other farmers whose perception of risks or business conditions are not compatible with such a fundamental economic shift.

Far more detrimental are the consequences of environmental events for coastal populations when human casualties are caused by severe storms. This was the case of storm Xynthia which hit the French Atlantic coast in February 2010, causing the death of 41 persons (Créac'h et al. 2015). For the first time in France, this dramatic event has resulted in the re-location of people, with no thorough assessment of alternative options. Créac'h et al. (this issue) have undertaken this comparative exercise of cost-effectiveness analysis for several adaptation strategies in a non-impacted area. They confirm that the most effective strategy is re-location, which is also the most costly operation. However, the authors also raise new questions about the way of measuring effectiveness.

\section{How to involve further stakeholders in the governance of marine systems?}

112

113

114

115

116

117

118

119

120

121

122

123

124

125

126

127

128

129

130

131

132

133

134

135

136

137

138

139

140

The right decisions for managing human uses can only be effective if the governing system is understood and well-accepted by populations (Bavinck et al. 2013), assuming good communication and permanent dialogue between the managers and stakeholders involved in marine social-ecological systems. This is what Tissière et al. (this issue) demonstrate by observing directly the nexus of exchanges between various actors socially embedded in a network of institutions involved in the management of demersal and benthic fisheries under the overarching umbrella of the Common Fisheries Policy (CFP). The authors adopted an ethnographic approach by participating as observers to a large set of meetings. They analysed the discursive content of these meetings to highlight the different perceptions and strategic roles of actors, and identify their action levers within the boundaries of the CFP legal framework.

Interestingly, Provost et al. (this issue) advocate for greater cooperation between fishers and scientists to improve governance as illustrated through a successful geo-foresight exercise. Scenarios of possible evolutions of the Bay of Biscay social ecological marine system are jointly created by these two groups and converted into quantitative inputs to be run by a bio-economic fisheries model, namely ISIS-Fish (Mahévas and Pelletier 2004), applied to mixed demersal fisheries. The outcomes of the simulations are then discussed between fishers and scientists to share a common understanding of the fishing system. This demonstration shows how flexible and useful models can be, under specific circumstances, to set up a dialogue and greater convergence of stakeholders towards the objectives of sustainable mixed fisheries.

Le Duff et al. (this issue) contribute with an article about Ouvea island in the West Pacific ocean, where environmental changes have a more tangible reality because of sea level rise and major flooding risks for atolls. They study the struggling strategies against coastal erosion by combining the scientific expertise with local and customary knowledge of the Kanak population. A participatory coastline monitoring system is designed firstly to share the data collection burden and access, and secondly to increase the awareness of local populations about the risk of sea level rise. 
The COSELMAR project results published in this special issue highlight that participatory science in all its dimensions (e.g., participatory research, community based research) (Houllier and Merilhou-Goudard 2016, Israel et al. 1998, Conrad et al. 2011) and multidisciplinary collaborations make it possible to 1 ) build bridges between science and society facilitating the exchange of knowledge, 2) enrich scientific approaches 3) raise awareness among stakeholders of evolutions in marine social-ecological systems to enhance the adaptive conditions coping with hazards and to make informed political choices.

150

151

152

153

154

155

156

157

158

159

160

161

162

163

164

165

166

167

168

169

170

171

172

173

174

175

176

177

178

179

180

181

182

183

184

185

186

187

The COSELMAR adventure has revealed the successful story of the two bi-disciplinary approaches initiated in this project. Both scientific developments have been performed by PhD students supervised by pairs of senior scientists respectively in human science and in natural science: Créach et al. (this issue) mixing geography and economics and Tissière et al. (this issue) mixing geography and fishery sciences. One key of success of these bidisciplinary PhD thesis, lies in the cross-cutting theme that is addressed. These kind of cross-cutting points of entry (e.g., risks, changes) remain the most obvious for engaging researchers in genuine transdisciplinary research and integrating the concepts of social systems and natural systems. These illustrations of transdisciplinary approaches should encourage more researchers to follow this track and go beyond two disciplinaries to address the complexity of social ecological systems.

Beyond the results presented in this special issue, the COSELMAR project has created broader knowledge on the complex social ecological system of the Bay of Biscay. It also gave the opportunity to open an arena between researchers from various disciplines through a research foresight exercise enabling to raise new questions dealing with marine social ecological systems. Two participatory and multidisciplinary research projects mixing science and art, currently in progress, have emerged from this foresight exercise, one on the imaginaries and representations of the sea and a second around scenarios and uncertainty.

This opportunity of mixing several disciplines to increase scientific knowledge on marine social and ecological systems and of creating links towards the stakeholders (including the civil society) relies on the management of a project with many partners, a significant budget dedicated to scientific dissemination and the willingness of researchers to go out of their disciplinary comfort zone so as to collaborate with other disciplines. It is therefore crucial to maintain the opportunities of funding big integrating projects such as COSELMAR and encouraging the development of management tools to facilitate the emergence of such projects.

\section{Acknowledgments}

The COSELMAR project was supported by grant from the Regional Council of the Pays de la Loire (Convention $\mathrm{n}^{\circ}$ 2012-09684, France). The OCEANEXT 2016 Conference was sponsored by the COSELMAR Project as well as by IFREMER, University of Nantes, University of Angers, IUML, MSH Ange-Guépin, Code Lutin, Crédit maritime, FEDER (L'Europe s'engage en Pays de la Loire), Nantes Métropole, Université du Maine, Le Mans Métropole, Conseil Général of the Sarthe, World Ocean Day and European Maritime Day. On behalf of the organizers, we are also very grateful to all the participants to the OCEANEXT 2016 conference. 
Bavinck, M., Chuenpagdee, R., Jentoft, S., Kooiman, J. (Eds) (2013) Governability of fisheries and aquaculture: theory and applications. Springer, Dordrecht, The Netherlands, Mare publication series, vol. 7. http://dx.doi.org/10.1007/978-94-007-6107-0

Berkes, F., Ross H. (2013) Community resilience: Toward an integrated approach. Society \& Natural Resources 26(1): 5-20, http://dx.doi.org/10.1080/08941920.2012.736605

Biggs, R., Schlüter, M., Schoon, M.L. (Eds) (2015) Principles for building resilience: sustainable ecosystem

services in social ecological systems. Cambridge University Press, Cambridge, UK.

Bograd, S.J., Kang, S., Di Lorenzo, E., Horii, T., Katugin, O.N., King, J.R., Lobanov, V.B., Makino, M., Na, G., Perry, R.I., Qiao, F., Rykaczewski, R.R., Saito, H., Therriault, T.W., Yoo, S., Batchelder, H. (2019) Developing a Social-Ecological-Environmental System Framework to Address Climate Change Impacts in the North Pacific. Frontiers of Marine Sciences 18. https://doi.org/10.3389/fmars.2019.00333

Conrad, C.C., Hilchey, K.G. (2011) A review of citizen science and community-based environmental monitoring: issues and opportunity. Environmental Monitoring and Assessment 176: 273-291. https://doi.org/10.1007/s10661-010-1582-5

Créach, A., Pardo, S., Guillotreau, P., Mercier, D. (2015) The use of a micro-scale index to identify potential death risk areas due to coastal flood surges: lessons from Storm Xynthia on the French Atlantic coast. Natural Hazards 77: 1679-1710. https://doi.org/10.1007/s11069-015-1669-y

Folke, C., Carpenter, S.R., Walker, B., Scheffer, M., Chapin, T., Rockström, J. (2010) Resilience thinking: integrating resilience, adaptability and transformability. Ecology and Society 15(4): 20. http://www.ecologyandsociety.org/vol15/iss4/art20/

Guillotreau P., Bundy A., Perry R.I. (Eds) (2018), Global change in marine systems, Integrating societal and governing responses. Routledge, Routledge Studies in Environment, Culture and Society (RSECS) Series, $330 \mathrm{p}$.

Houllier, F., Merilhou-Goudard, J.B. (2016) Les sciences participatives en France. Etat des lieux, bonnes pratiques et recommandations. Rapport aux ministres en charge de l'Éducation nationale, de l'Enseignement supérieur et de la Recherche, 122. http://www.sciences-participatives.com/Rapport

213 Israel, B.A., Schulz, A.J., Parker, E.A., Becker, A.B. (1998) Review of Community-Based Research: Assessing 214 Partnership Approaches to Improve public Health. Annual Review of Public Health 19:173-202. 215 https://doi.org/10.1146/annurev.publhealth.19.1.173

216 Krishnamurty, R.R., Jonathan M.P., Srinivasalu S., Glaeser B. (Eds) (2018) Coastal management: Global 217 challenges and innovations. Academic Press, 1st edition, 546 p.

218 Lang, D.J., Wiek, A., Bergmann, M., Stauffacher, M., Martens, P., Moll, P., Swilling, M., Thomas, C.J. (2012) 219 Transdisciplinary research in sustainability science: practice, principles, and challenges. Sustain Science 7: 25220 43. https://doi.org/10.1007/s11625-011-0149-x

221 Mahévas, S., Pelletier, D. (2004) ISIS-Fish, a generic and spatially-explicit simulation tool for evaluating the 222 impact of management measures on fisheries dynamics. Ecological Modelling 171(1-2): 65-84. 223 https://doi.org/10.1016/j.ecolmodel.2003.04.001

224 MDG Gap Task Force Report (2015) Millennium Development Goal 8. Taking Stock of the Global Partnership for 225 Development. United Nations publication, New-York, 75.

226 Van Assche, K., Hornidge, A.K., Schlüter, A., Vaidianu, N. (2020) Governance and the coastal condition: 227 Towards new modes of observation, adaptation and integration. Marine Policy 112. 228 https://doi.org/10.1016/j.marpol.2019.01.002

[1] Two OCEANEXT conferences were held in Nantes in summer 2016 and 2019. The contributions to this special 231 [1] Two OCEANEXT conferences were held
232 issue were presented in the first edition. 
296

297

298

299

300

301

302

303

304

305

306

307

308

309

310

311

312

313

314

315

316

317

318

319

320

321

322

323

324

325

326

327

328

329

330

331

332

333

334

335

336

337

338

339

340

341

342

343

344

345

346

347

348

349

350

351

352

353

354

234 [3] https://oceanext.sciencesconf.org/

235 [4] https://oceanext-2019.sciencesconf.org/ 